\title{
Artificial aortic valve dysfunction due to pannus and thrombus - different methods of cardiac surgical management
}

\author{
Stanisław Ostrowski, Anna Marcinkiewicz, Anna Kośmider, Andrzej Walczak, Radosław Zwoliński, \\ Ryszard Jaszewski
}

Department of Cardiac Surgery, Medical University of Lodz, Poland

Kardiochirurgia i Torakochirurgia Polska 2015; 12 (3): 199-203

\begin{abstract}
Introduction: Approximately 60000 prosthetic valves are implanted annually in the USA. The risk of prosthesis dysfunction ranges from $0.1 \%$ to $4 \%$ per year. Prosthesis valve dysfunction is usually caused by a thrombus obstructing the prosthetic discs. However, $10 \%$ of prosthetic valves are dysfunctional due to pannus formation, and $12 \%$ of prostheses are damaged by both fibrinous and thrombotic components. The authors present two patients with dysfunctional aortic prostheses who were referred for cardiac surgery. Different surgical solutions were used in the treatment of each case.

Case study 1: The first patient was a 71-year-old woman whose medical history included arterial hypertension, stable coronary artery disease, diabetes mellitus, chronic obstructive pulmonary disease (COPD), and hypercholesterolemia; she had previously undergone left-sided mastectomy and radiotherapy. The patient was admitted to the Cardiac Surgery Department due to aortic prosthesis dysfunction. Transthoracic echocardiography revealed complete obstruction of one disc and a severe reduction in the mobility of the second. The mean transvalvular gradient was very high. During the operation, pannus covering the discs' surface was found. A biological aortic prosthesis was reimplanted without complications.

Case study 2: The second patient was an 87-year-old woman with arterial hypertension, persistent atrial fibrillation, and COPD, whose past medical history included gastric ulcer disease and ischemic stroke. As in the case of the first patient, she was admitted due to valvular prosthesis dysfunction. Preoperative transthoracic echocardiography revealed an obstruction of the posterior prosthetic disc and significant aortic regurgitation. Transesophageal echocardiography and fluoroscopy confirmed the prosthetic dysfunction. During the operation, a thrombus growing around a minor pannus was found. The thrombus and pannus were removed, and normal functionality of the prosthetic valve was restored.

Conclusions: Precise and modern diagnostic methods facilitated selection of the treatment method. However, the intraoperative view also seems to be crucial in individualizing the surgical approach.
\end{abstract}

Key words: pannus, thrombus, artificial valve, echocardiography.

\section{Streszczenie}

Wstęp: Szacuje się, że w USA rocznie wykonuje się blisko 60000 implantacji sztucznej zastawki serca. Ryzyko dysfunkcji protezy zastawkowej wynosi 0,1-4\% na rok. Najczęściej związane jest z powstaniem skrzepliny blokującej dyski. W ok. $10 \%$ przypadków wiąże się z powstaniem łuszczki. Strukturę o mieszanej budowie, zajmującą sztuczną zastawkę, stwierdza się w $12 \%$ przypadków. Autorzy pracy przedstawili postępowanie kardiochirurgiczne w przypadku 2 pacjentek z dysfunkcją sztucznej zastawki aortalnej - z powodu łuszczki u pierwszej oraz łuszczki ze skrzepliną u drugiej.

Przypadek 1: 71-letnia pacjentka z nadciśnieniem tętniczym, stabilną chorobą wieńcową, cukrzycą typu 2, przewlekłą obturacyjną chorobą płuc (POChP) i hipercholesterolemią, po przebytej mastektomii lewostronnej i radioterapii została przyjęta do Kliniki Kardiochirurgii w maju 2011 r. z powodu dysfunkcji sztucznej zastawki aortalnej. Przedoperacyjna przezklatkowa echokardiografia wykazała brak ruchomości jednego z dysków sztucznej zastawki ze znacznym ograniczeniem ruchomości drugiego dysku i wysokim gradientem przezzastawkowym. Śródoperacyjnie potwierdzono obecność łuszczki. Przeprowadzono reimplantację bioprotezy aortalnej.

Przypadek 2: 87-letnia pacjentka z nadciśnieniem tętniczym, POChP, chorobą wrzodową w wywiadzie, utrwalonym migotaniem przedsionków, po udarze niedokrwiennym lewostronnym została przyjęta do Kliniki Kardiochirurgii z powodu dysfunkcji sztucznej zastawki aortalnej. Przedoperacyjna echokardiografia przezklatkowa i przezprzełykowa oraz fluoroskopia ujawniły zablokowanie tylnego dysku powodujące znaczną niedomykalność aortalną. Śródoperacyjnie potwierdzono obecność skrzepliny i łuszczki, przywracając dobrą funkcję protezy.

Wnioski: Pomimo zastosowania szczegółowej diagnostyki przedoperacyjnej, ocena śródoperacyjna pozwoliła na zindywidualizowanie podejścia kardiochirurgicznego.

Słowa kluczowe: łuszczka, skrzeplina, sztuczna zastawka, echokardiografia.

Address for correspondence: Stanisław Ostrowski, MD, PhD, Department of Cardiac Surgery, Medical University of Lodz, 251 Pomorska St., 92-213 Lodz, Poland, phone/fax: +42 20244 60/61, e-mail: stanislaw.ostrowski@umed.lodz.pl 


\section{Introduction}

Approximately 60000 prosthetic valves are annually implanted in the USA [1]. Currently, implantation of an aortic prosthesis is one of the most commonly performed cardiac surgery procedures. The associated perioperative mortality does not exceed $2.5 \%$ [2]. Age and narrow native ostium are the main risk factors influencing perioperative mortality [2]. The risk of prosthesis dysfunction is $0.1-4 \%$ per year [3]. Mechanical prostheses are more likely to become dysfunctional. A thrombus obstructing the prosthetic discs is the most common cause of dysfunction. Only in $10 \%$ of cases are the prostheses damaged by pannus. However, either a thrombus can become fibrinated and resemble pannus, or pannus can stimulate thrombus formation on its surface and, consequently, resemble a thrombus. Such clinical situations in which both thrombotic and fibrous components are present are observed in $12 \%$ of cases of prosthesis dysfunction. Pannus is usually observed later after the surgery, usually after 5 years. Most often, pannus forms on the aortic side, whereas a thrombus develops more frequently on the mitral prosthesis. What is more, thrombus development is mainly associated with sudden aggravation of the clinical condition. The perioperative period is crucial for thrombus formation. Regardless of the time between the operation and prosthesis dysfunction, insufficient oral anticoagulation is the most common cause of thrombus formation [4]. None of the symptoms of prosthesis dysfunction, such as deterioration of exertion tolerance, exacerbating dyspnea, syncopes, or lack of the metallic sound of prosthesis closure, allow for differentiation between the two structures pannus and thrombus. However, intraoperative assessment facilitates the choice of an appropriate final approach. The authors present two different surgical solutions for aortic prosthesis dysfunction of various etiologies.

\section{Case studies}

\section{Case study 1}

The patient was a 71-year-old woman whose medical history included arterial hypertension, stable coronary artery disease, diabetes mellitus type 2 (oral medications), chronic pulmonary obstructive disease (COPD), and hypercholesterolemia; she had previously undergone left-sided mastectomy and radiotherapy (1990). She was admitted to the cardiac surgery department in May 2011 due to aortic prosthesis dysfunction. In 2005, the patient had simultaneously undergone the implantation of an aortic prosthetic valve (St. Jude A21), mitral valve repair using Wooler's method, and coronary artery bypass grafting (CABG) of the right coronary artery (RCA). On admission, the patient was classified as NYHA (New York Heart Association) functional class IV. Preoperative transthoracic echocardiography (TTE) showed an immobile prosthetic disc and a major reduction in mobility of a second. The transvalvular gradient was high (maximal: $87 \mathrm{mmHg}$, mean: $44 \mathrm{mmHg}$ ). Based on the TTE image, the diagnosis of pannus or thrombus was taken into consideration. A moderate aortic valve insufficiency co-existed with a moderate mitral insufficiency and a secondary mild tricuspid valve insufficiency. The left atrium was enlarged to $5.6 \times 4.4 \mathrm{~cm}$. The left ventricle was hypertrophic - the systolic diameter was $3.3 \mathrm{~cm}$, and the diastolic diameter was $5.0 \mathrm{~cm}$. The systolic and diastolic thickness of the interventricular septum was, respectively, 1.7 and $1.4 \mathrm{~cm}$. The right atrium and ventricle were slightly enlarged.

Hypokinesis of the postero-inferior cardiac wall within the parabasal and medial segments was revealed. A good ejection fraction (EF) was confirmed (52\%). Echocardiographic presentation and the patient's clinical condition proved that urgent surgery and prosthesis replacement were required.

During the operation, pannus was found. Its solid, cohesive tissue structure suggested a rather long-lasting prosthesis dysfunction. A redo procedure was conducted, and an aortic bioprosthesis (Medtronic Hancock II 21) was implanted. The previously performed mitral repair did not require any correction. The perfusion time was $129 \mathrm{~min}$, and the cross-clamping time was $100 \mathrm{~min}$. Cardioprotection was obtained with $1700 \mathrm{ml}$ of a cold, crystalloid, cardioplegic solution, administered antegrade and non-continuously. The patient was extubated in the morning of the first postoperative day. Control postoperative echocardiography showed that the bioprosthesis reimplantation had been successful (max gradient: $30 \mathrm{mmHg}$ ).

\section{Case study 2}

The patient was an 87-year-old woman with arterial hypertension, COPD, persistent atrial fibrillation, and a past history of ulcer disease and ischemic stroke (2 months earlier). She was admitted to the cardiac surgery department in 2011, due to an aortic prosthesis dysfunction (St. Jude A21 implanted in 2000). Ten days before the operation, the patient was admitted to the cardiology department in order to undergo the reimplantation of a stimulating device (stimulator Biotronik Actros S-VVI and ventricular electrode Biotronik PX 60-BP) implanted in 2002 due to $2^{\text {nd }} / 3^{\text {rd }}$ degree atrioventricular block (her medical history included numerous rhythm and conductibility disturbances causing recurrent MAS syndrome). Before the reimplantation of the stimulating device, at an appropriate time, clopidogrel (taken by the patient since the stroke - allergic to acetylsalicylic acid) and oral anticoagulation were stopped, and lowmolecular-weight heparin (LMWH) was introduced instead (enoxaparin). On admission, the patient was classified as NYHA functional class III. She complained only of easy fatigue, worse exertion tolerance, and weakness. The stimulator was reimplanted without complications. During the patient's stay at the cardiology department, TTE revealed abnormal function of the aortic prosthesis, with a significant transvalvular gradient $(64 \mathrm{mmHg})$. Urgent fluoroscopy was performed (Fig. 1 and 2). Transesophageal echocardiography (TEE) was also conducted. Both examinations confirmed good mobility of the anterior half-disc and an obstruction of the posterior half-disc resulting in significant aortic regurgitation. The blocked disc interfered with the 


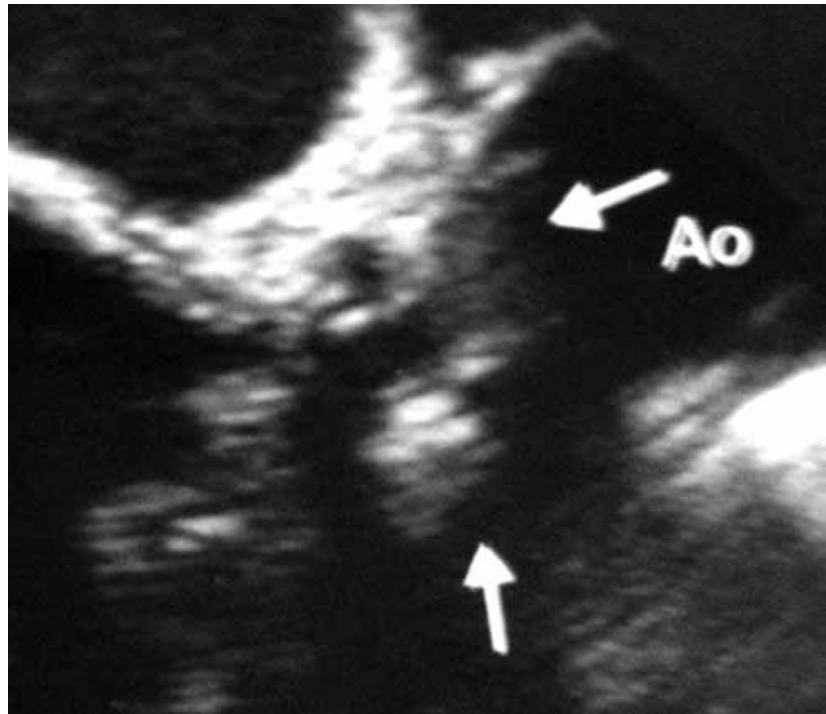

Fig. 1. Transthoracic echocardiography - image of a mass resembling a slightly attached thrombus and obstructing the artificial aortic valve

blood outflow, giving the symptoms of valve stenosis. Moderate mitral insufficiency with thickened valve leaflets and functional moderate tricuspid insufficiency were also discovered. Moderate pulmonary hypertension was present. Systolic pulmonary artery pressure (SPAP) was $50 \mathrm{mmHg}$. The left atrium was enlarged to $6.6 \times 5.1 \mathrm{~cm}$ (volume $140 \mathrm{ml}$ ). No thrombus was observed. Significant left ventricular hypertrophy was found, but the EF was relatively good (54\%). Coronarography showed no changes. Ultrasonography of the carotid vessels revealed bilateral atherosclerotic changes, but without significant flow disturbances. Intraoperatively, a thrombus growing around pannus was discovered. Based on the assessment of the aortic prosthesis, a decision was made to repair it. After the removal of slightly attached thrombotic components, the soft tissue of the pannus became clearly visible. The pannus was removed from the ventricular side of the prosthesis, which resulted in good mobility of the half-discs. The surgery was conducted under extracorporeal circulation, in mild hypothermia $\left(32^{\circ} \mathrm{C}\right)$. Total perfusion time was 94 minutes, and aortic cross-clamping time was 59 minutes. Cardioprotection was achieved with $1300 \mathrm{ml}$ of a cold, crystalloid, cardioplegic solution, administered antegrade. Intraoperative TEE was conducted, confirming normal functionality of the prosthesis, while revealing slight aortic insufficiency and a maximal transvalvular gradient of $30 \mathrm{mmHg}$ (Fig. 3). Moderate mitral insufficiency was also present. The global contractility of the left ventricle was reduced. The patient was extubated in the afternoon of the first postoperative day. After the surgery, the patient required temporary external heart stimulation. Acute kidney injury was observed (urea $15 \mathrm{mmol} / \mathrm{l}$ and creatinine $225 \mu \mathrm{l} / \mathrm{l})$. The patient was also disoriented and incoherent. Therapy with theophylline and piracetam was introduced, resulting in significant clinical improvement. Consequently, on the fourth day after the operation, the patient was discharged from the ICU. Control TTE examinations were per-

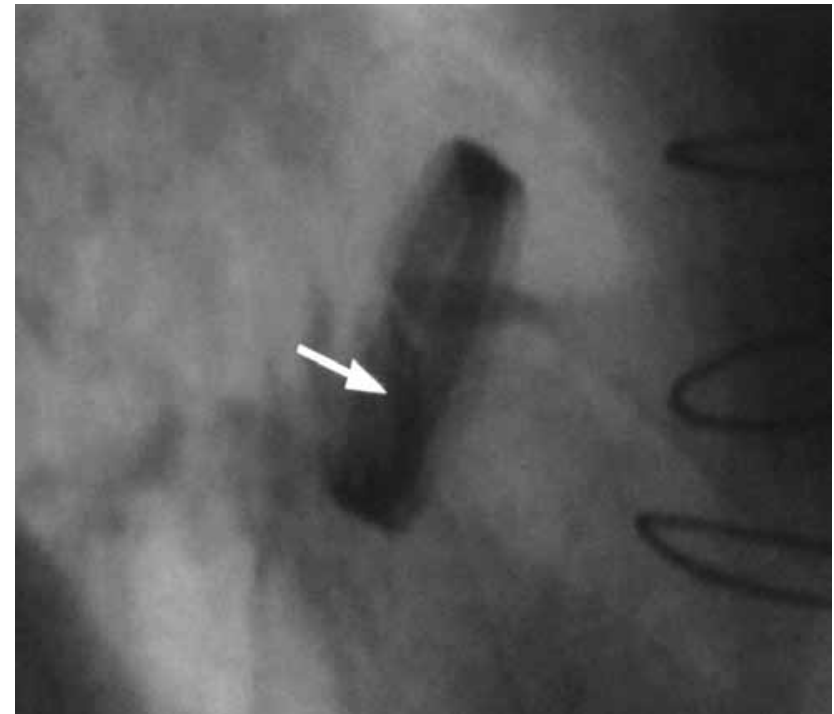

Fig. 2. Fluoroscopy image - the arrow points to the outline of the structure impairing the mobility of the prosthetic valve disc

formed on the $4^{\text {th }}$ and $12^{\text {th }}$ postoperative days. Their results confirmed the success of the removal of the pannus and thrombus from the aortic prosthesis, showing a maximal gradient of $30 \mathrm{mmHg}$. Slightly worse global contractility of the myocardium, especially of the postero-inferior wall, with a decreased EF of $52 \%$, was also observed.

\section{Discussion}

Pannus is a granulation tissue which develops as part of the healing process. According to Teshima et al. [5], increased levels of TGF- $\beta 1$ in patients with artificial aortic valves stimulate the overgrowth of granulation tissue, giving rise to pannus.

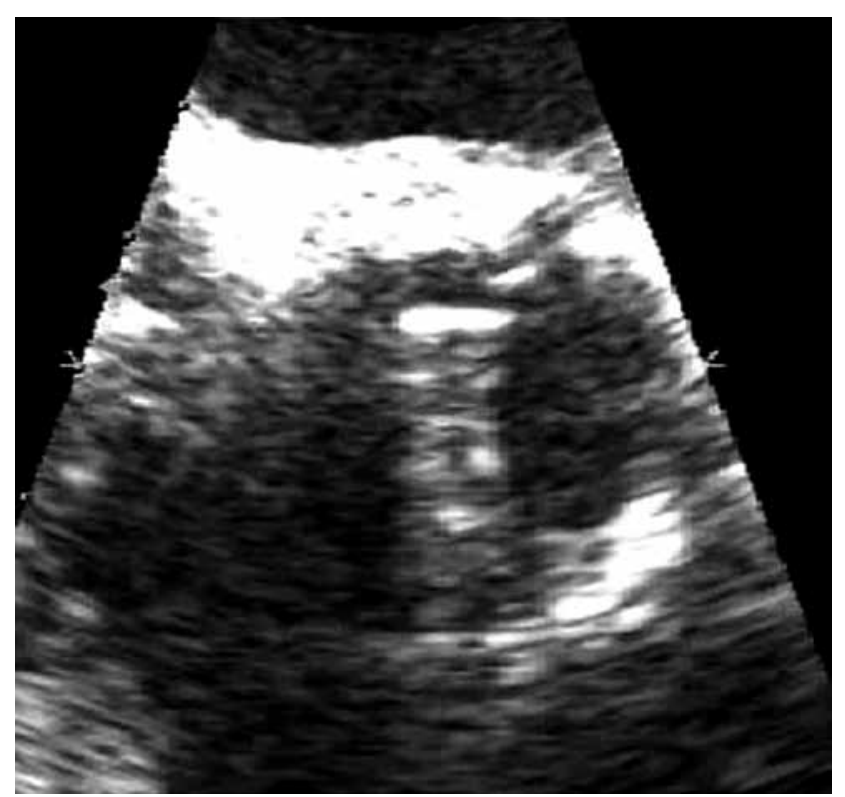

Fig. 3. Transesophageal echocardiography - intraoperative image of the properly functioning aortic prosthetic valve: visualized open discs (after removal of the pannus with thrombus) 
Pannus is more closely connected with the prosthetic surface, so its removal is related to a greater risk of mechanical valve damage. Studies report good results of pannus removal, instead of prosthesis reimplantation [6]. Song et al. [7] also described positive effects of pannus removal after mitral valve ring annuloplasty. However, we have not found any case involving the removal of both pannus and thrombus from an aortic prosthesis. In the case of our first patient, well-formed pannus was closely connected to the prosthesis, completely excluding the possibility of its removal; reimplantation was the only solution. In the second case, the balloting thrombus and minor soft pannus were easy to remove. Considering the patient's age, the operative risk was high. Additionally, both women were in poor biological condition. Moreover, redo procedures are always associated with higher risk [8]. On the other hand, some authors have proved that reoperation is not an independent risk factor for operative mortality. The mortality of elective redo procedures is estimated at $1.4 \%$, which is comparable with the mortality associated with primary aortic valve replacement $[9,10]$. The clinical course of prosthesis dysfunction can sometimes prove to be serious and may include pulmonary edema and cardiogenic shock [11]. In the case of our first patient, the circulatory failure was severe. However, the patient was stable enough to be adequately prepared for surgery. In contrast, the second patient was almost asymptomatic. However, a thrombus could have been suspected just after the stroke; it could have resulted from an embolic event, especially as it developed during the cessation of oral anticoagulation and clopidogrel. The presence of both pannus and thrombus could have suggested that the discontinuation of oral anticoagulation resulted in thrombus formation around the previously present pannus despite LMWH treatment (enoxaparin). The recently formed thrombus was susceptible to fragmentation and associated with a high embolic risk. Embolic events, inadequate oral anticoagulation, and deterioration of circulatory condition are the primary indications of the presence of a thrombus on a valvular prosthesis [12]. Transesophageal echocardiography is commonly used to diagnose thrombus or pannus on an artificial valve. Barbetseas et al. [3] evaluated the sensitivity of TEE in diagnosing prosthesis dysfunction at $83 \%$. Only small structures posed problems, especially if the dysfunction was caused by pannus interfering with the hinges of the prosthesis. In our observation, echocardiography in combination with the patient's medical history allowed a final diagnosis to be established. In both cases, TTE was the first line in the examination process. It gave indirect evidence of a mass blocking the prosthetic valve. During the examination of the first patient, a mass of higher echogenicity than a thrombus was visualized. It extended from the suture line to the discs' surface and beneath. The final diagnosis was made considering the time period from the primary operation (6 years) and aortic prosthesis involvement. The patient's history suggested good compliance with oral anticoagulation. The second patient's history also suggested this diagnosis. Fluoroscopy confirmed the obstruction of the posterior half-disc. Additionally, TEE showed a large mass slightly attached to the prosthesis, whose echogenicity was lower. This view was suggestive of a thrombus. Kuniyoshi et al. [13] emphasized the value of multimodal diagnostics in precisely imaging the changes on a prosthesis that manifest poorly. The clinical condition of our patients correlated relatively well with the echocardiographic image. According to some authors [14], echocardiographic data and clinical criteria are not sufficient to differentiate between pannus and thrombus. The subject literature also underlines the value of spiral tomography and fluoroscopy in diagnosing the cause of prosthesis dysfunction (pannus or thrombus) $[15,16]$. The risk of thrombus development on an aortic prosthesis is estimated at $0.2-6 \%$ per year per patient. The embolic event rate is reported at $1.8 \%$ of patients per year [1]. In such cases, surgery is the preferred treatment of choice. According to some authors [12], thrombolytic treatment should be chosen in the case of small thrombi, regardless of circulatory failure (which is also in accordance with the recommendations of the American College of Chest Physicians). However, according to the recommendations for managing left heart thrombi, thrombolysis should be applied: in patients classified as NYHA functional class III or IV with high operative risk and in patients classified as functional NYHA class I or II when the thrombus is immobile or situated in the left atrium [17]. In our second patient, considering the previous stroke and age, thrombolysis would have been associated with a greater risk of complications.

\section{Conclusions}

1. Emphasis should be put on the early diagnosis of prosthesis dysfunction, which allows for the avoidance of complications and decreases the operative risk.

2. The reported cases confirm the role of echocardiography in diagnosing thrombus and pannus as a cause of prosthesis dysfunction.

3. Preoperative diagnostics facilitated the selection of surgical treatment. However, the surgical approach was individualized during surgery.

4. The role of adequate anticoagulation, reducing the risk of thromboembolic complications, must be once again underlined. Any change in the type of anticoagulation is especially significant and requires careful monitoring of the patient.

\section{Disclosure}

Authors report no conflict of interest.

\section{References}

1. Kardon EM. Prosthetic Heart Valves; http://emedicine.medscape.com/ article/780702-overview\#a0199.

2. Jander S, Bitner M, Jegier B, Ostrowski S, Jaszewski R. Early outcome of aortic valve replacement with mechanical prosthesis in patients with aortic stenosis. Is patient-prosthesis mismatch a significant clinical problem? Arch Med Sci 2007; 3: 57-60.

3. Barbetseas J, Nagueh SF, Pitsavos C, Toutouzas PK, Quinones MA, Zoghbi WA. Differentiating thrombus from pannus formation in obstructed 
mechanical prosthetic valves: an evaluation of clinical, transthoracic and transesophageal echocardiographic parameters. J Am Coll Cardiol 1998; 32: 1410-1417.

4. Sangareddi $V$. What is pannus formation in prosthetic valves? What is the clinical significance? http://www.wellsphere.com/heart-health-article/whatis-pannusformation-in-prosthetic-valves-what-is-the-clinical-significance/ 629218.

5. Teshima H, Fukunaga S, Takaseya T, Tomoeda H, Akashi H, Aoyagi S. Obstruction of St. Jude medical valves in the aortic position: plasma transforming growth factor type beta 1 in patients with pannus overgrowth. Artif Organs 2010; 34: 210-215.

6. Park B, Park PW, Park CK. Transaortic chordae and pannus removal with out redo mitral valve replacement in prosthetic mitral valve malfunction. Eur J Cardiothorac Surg 2011; 39: 1057-1058.

7. Song S, Cho SH, Yang JH, Park PW. Repair for mitral stenosis due to pannus formation after Duran ring annuloplasty. Ann Thorac Surg 2010; 90: e93-94.

8. Maciejewski M, Piestrzeniewicz K, Bielecka-Dąbrowa A, Piechowiak M, Jaszewski R. Redo surgery risk in patients with cardiac prosthetic valve dysfunction. Arch Med Sci 2011; 7: 271-277.

9. Vogt PR, Brunner-LaRocca HP, Sidler P, ZuEnd G, Truniger K, Lachat M, Turina J, Turina MI. Reoperative surgery for degenerated aortic bioprostheses: predictors for emergency surgery and reoperative mortality. Eur J Cardiothorac Surg 2000; 17: 134-139.

10. Davierwala PM, Borger MA, David TE, Rao V, Maganti M, Yau TM. Reoperation is not an independent predictor of mortality during aortic valve surgery. J Thorac Cardiovasc Surg 2006; 131: 329-335.
11. Mullenix PS, Parsa CJ, Mackensen GB, Jollis JG, Harrison JK, Hughes GC. Pannus-related prosthetic valve dysfunction and life-threatening aortic regurgitation. J Heart Valve Dis 2008; 17: 666-669.

12. Shapira Y, Vaturi M, Sagie A. Obstructive left-sided prosthetic valve thrombosis. Acute Card Care 2009; 11: 160-168.

13. Kuniyoshi Y, Koja K, Miyagi K, Shimoji M, Uezu T, Arakaki K, Yamashiro S, Mabuni K, Senaha S, Nakasone Y. Pannus formation in aortic valve prostheses in the late postoperative period. J Artif Organs 2003; 6: 179-182.

14. Hurwitz SE, Waxman D, Hecht S. Acute failure of a St. Jude's prosthetic aortic valve: large pannus formation masked by a small thrombus. I Am Soc Echocardiogr 2009; 22: 1086.e1-3.

15. Tsai IC, Lin YK, Chang Y, Fu YC, Wang CC, Hsieh SR, Wei HJ, Tsai HW, Jan SL, Wang KY, Chen MC, Chen CC. Correctness of multi-detector-row computed tomography for diagnosing mechanical prosthetic heart valve disorders using operative findings as a gold standard. Eur Radiol 2009; 19: 857-867.

16. Licata A, Matthai WH Jr. Evaluating the etiology of mechanical valve obstruction: use of clinical parameters, fluoroscopy, and echocardiography. Cathet Cardiovasc Intervent 2002; 55: 495-500.

17. Lengyel M, Fuster V, Keltai M, Roudaut R, Schulte HD, Seward JB, Chesebro JH, Turpie AGG. Guidelines for management of left-side prosthetic valve thrombosis: a role for thrombolytic therapy. J Am Coll Cardiol 1997; 30: 1521 1526. 